\title{
The Effect of Soil pH and Related Acidity Factors on Yield of Plantains (cv Maricongo) Grown on Los Guineos Clay, an Ultisol ${ }^{1,2}$
}

\author{
Raúl Pérez Escolar and M. A. Lugo-López ${ }^{3}$
}

\begin{abstract}
The effect of soil $\mathrm{pH}$ and related acidity factors on yield and foliar composition of plantains (cv Maricongo) grown on Los Guineos clay, an Ultisol, has been determined in a plant crop and a first ratoon. In the former, only soil $\mathrm{pH}$ was correlated in a significant way with number of fruits per bunch, $r=0.47$ with $Y$ $=322.73+134.41 x-12.32 x^{2}$, to predict this yield parameter at a particular $\mathrm{pH}$ in the range of 4.4 and 5.2. Leaf calcium content was related in a highly significant way $(r=0.70)$ with number of fruits per bunch. In the first ratoon, no significant correlations were measured between soil acidity indices and the yield parameters, nor between nutrients in the leaves and plantain yields. Plantain cultivar Maricongo seems to be highly tolerant to low soil pH and correspondingly high ionic aluminum.
\end{abstract}

\section{INTRODUCTION}

The soil forming processes of Oxisols and Ultisols are conducive to intense base and silica leaching, subsequent circulation of aluminum and manganese, and partial precipitation of their hydroxides. Ionic aluminum and manganese present a major threat for most crops, particularly when acid fertilizers act on their hydroxides. Plant physiological processes, and consequently, crop yields, are affected. Sound liming practices overcome base removal and inactivate harmful aluminum and manganese to a good extent.

Liming acid soils has raised questions about the degree in which different factors cause crops to respond differentially to lime within a given soil and among a wide variety of soils with the same $\mathrm{pH}$. The effect of soil $\mathrm{pH}$ and related acidity factors has shown that soil chemical properties are as important as physical and biological properties where optimum growth and crop yield are considered. The present study was oriented toward relating the soil characteristics associated with acidity to the yield and foliar composition of plantains (cv Maricongo).

'Manuscript submitted to editorial Board March 2, 1978.

${ }^{2}$ Joint contribution from the Agricultural Experiment Station, University of Puerto Rico, Mayagüez Campus, Río Piedras, P. R., and the Department of Agronomy, Cornell University, Ithaca, N. Y. This study was part of the investigation supported by U.S. AID under research contract tact-0-1104 entitled "Soil fertility in the humid tropics."

${ }^{3}$ Soil Scientist, Agricultural Experiment Station, Mayagüez Campus, University of Puerto Rico, Río Piedras, P. R., and Professor and Soil Scientist (Ret.) Agri. Exp. Stn. University of Puerto Rico, now consultant, Cornell University, respectively. 


\section{MATERIALS AND METHODS}

The experiment was conducted in Los Guineos clay, located in Barrio Mameyes in Jayuya. It is an Epiaquic Tropohumults derived from tuffaceous material ${ }^{4}$. Its slope is around $40 \%$ with northern exposure, and occurs in the midst of the coffee area, $600 \mathrm{~m}$ above sea level. Its original $\mathrm{pH}$ was 4.1 and the cation exchange capacity is $16.0 \mathrm{meq} / 100 \mathrm{~g}$, as determined by ammonium acetate buffered at $\mathrm{pH}$ 7.0. Lime applications were made in July 1970, after which field corn, snapbeans, sweetpotatoes and soybeans were planted in that order. These results have been reported by Abruña et al. ${ }^{5}$ and by Pérez Escolar ${ }^{6}$. Five treatments, replicated five times, were arranged in a Latin square design. They consisted of check, $337 \mathrm{~kg} / \mathrm{ha}$ of $\mathrm{Ca}(\mathrm{OH})_{2}$, and sufficient lime to bring soil $\mathrm{pH}$ to $5.5,6.0$ and 7.0 .

The experiment was planted on June 14,1974 . Plot size was $4.6 \times 7.6$ $\mathrm{m}$, and the planting distance was $1.54 \times 1.85 \mathrm{~m}$, with a total of 12 plants per plot. Prior to planting, $2 \mathrm{oz}$ of triple superphosphate were placed on the bottom of each hole of approximately $0.027 \mathrm{~m}^{3}$. The peeled corms, treated with a mixture of Nemagon and Aldrin, ${ }^{7}$ varied from about $120 \mathrm{~g}$ to $600 \mathrm{~g}$ in weight, but they were randomly distributed within the plots, to prevent bias.

One mo and 5 mo after planting, $227 \mathrm{~g}$ of a 15-5-10 fertilizer mixed with $\mathrm{Mg}$ at the rate of $56 \mathrm{~kg} / \mathrm{ha}$ were applied to each plant. When the plants were 9 mo old, another $227 \mathrm{~g}$ of a 10-5-15 fertilizer was applied to each plant. No Mg was added this time. With each fertilizer application, Dasanit was administered to each plant to control nematodes. When the plants were around 8 mo old, orchard oil was sprayed on the leaves with a motor blow machine every 3 weeks, to control Sigatoka disease.

At the time of bunch shooting, leaves \#3 were collected and analyzed for $\mathrm{N}, \mathrm{P}, \mathrm{K}, \mathrm{Ca}, \mathrm{Mg}$ and $\mathrm{Mn}$.

Crop harvest took place from October 22, 1975 to February 23, 1976.

${ }^{4}$ Lugo-López, M. A. and Rivera, L. H., 1976. Taxonomic classification of the soils of Puerto Rico, Agri. Exp. Stn. Univ. P. R. Bull. 245.

${ }^{5}$ Abruña, F., Pearson, R. W., and Pérez Escolar, R., 1976. Lime response of corn and beans grown on typical Oxisols and Ultisols of P. R., 261-81. In Elemer Bornemisza and Alfredo Alvarado (Ed) Soil Management in Tropical America, North Carolina State University Press, 1975.

${ }^{6}$ Pérez-Escolar, R., 1977. Effect of soil $\mathrm{pH}$ and related acidity factors on yields of sweetpotatoes and soybeans grown on typical soils of the humid tropics, J. Agri. Univ. P. R. 61 (1): $82-9$.

Trade names are used in this publication solely for the purpose of providing specific information. Mention of a trade name does not constitute a guarantee or warranty of equipment or materials by the Agricultural Experiment Station of the University of Puerto Rico or an endorsement over other equipment or materials not mentioned. 
TABLE 1.-The effect of soil $\mathrm{pH}$ and related acidity factors on number of fruits per bunch, weight of bunch and weight per fruit of plantain cultivar Maricongo (plant crop) grown on Los Guineos clay, an Ultisol

\begin{tabular}{|c|c|c|c|c|c|c|}
\hline Soil pH & $\begin{array}{l}\text { Exchangea- } \\
\text { ble Al } \\
\text { meq/100 g }\end{array}$ & $\begin{array}{l}\text { Exch. bases } \\
\text { meq/100 g }\end{array}$ & $\begin{array}{l}\text { Base sat- } \\
\text { uration }\end{array}$ & $\begin{array}{l}\text { Number of } \\
\text { fruits }^{1}\end{array}$ & Wt. of bunch & Wt. per fruit \\
\hline & & & $\%$ & & $K g$ & $G$ \\
\hline $4.4-4.6$ & 2.63 & 1.50 & 36 & 33 & 10.5 & 322 \\
\hline $4.6-4.8$ & 1.99 & 2.21 & 53 & 39 & 11.8 & 300 \\
\hline $4.8-5.0$ & 1.30 & 2.58 & 67 & 36 & 10.2 & 286 \\
\hline$>5.0$ & 0.68 & 4.59 & 87 & 38 & 11.3 & 300 \\
\hline
\end{tabular}

TABLE 2.-The effect of soil $p H$ on foliar composition of plantain cultivar Maricongo (plant crop) grown on Los Guineos clay, an Ultisol

\begin{tabular}{ccccccc}
\hline \multirow{2}{*}{ Soil $\mathrm{pH}$} & \multicolumn{7}{c}{ Foliar Composition } \\
\cline { 2 - 7 } & $\mathrm{N}$ & $\mathrm{P}$ & $\mathrm{K}$ & $\mathrm{Ca}^{1}$ & $\mathrm{Mg}$ & $\mathrm{Mn}$ \\
\hline & $\%$ & $\%$ & $\%$ & $\%$ & $\%$ & $p / m$ \\
$4.4-4.6$ & 3.66 & 0.17 & 3.95 & 0.38 & 0.44 & 1.34 \\
$4.6-4.8$ & 3.70 & 0.17 & 3.06 & 0.42 & 0.40 & 118 \\
$4.8-5.0$ & 3.53 & 0.15 & 3.09 & 0.71 & 0.40 & 90 \\
$>5.0$ & 3.71 & 0.14 & 2.55 & 0.62 & 0.36 & 90 \\
\hline
\end{tabular}

${ }^{1}$ Was correlated in a highly significant way $\left(r=0.70^{* *}\right)$ with number of fruits per bunch.

TABLE 3. - The effect of soil $\mathrm{pH}$ and related acidity factors on number of fruits per bunch, bunch weight and average fruit weight of plantain cultivar Marirungo producing more than 40 fruits per bunch

\begin{tabular}{ccccccc}
\hline Soil pH & $\begin{array}{c}\text { Exchangeable } \\
\text { Al meq/100 g }\end{array}$ & $\begin{array}{c}\text { Exchangeable } \\
\text { bases meq/ } \\
100 \mathrm{~g}\end{array}$ & $\begin{array}{c}\text { Base } \\
\text { saturation }\end{array}$ & $\begin{array}{c}\text { Number of } \\
\text { fruits }\end{array}$ & $\begin{array}{c}\text { Weight of } \\
\text { bunch }\end{array}$ & $\begin{array}{c}\text { Weight per } \\
\text { fruit }\end{array}$ \\
\hline & & & $\%$ & & $K g$ & $G$ \\
$4.4-4.6$ & 2.56 & 1.89 & 42 & 42 & 13.4 & 318 \\
$4.6-4.8$ & 1.93 & 2.40 & 55 & 46 & 13.0 & 286 \\
$4.8-5.0$ & 1.56 & 2.53 & 62 & 43 & 12.0 & 277 \\
$>5.0$ & 0.93 & 3.72 & 80 & 45 & 13.2 & 295 \\
\hline
\end{tabular}

TABLE 4.-The effect of soil $p H$ and related acidity factors on number of fruits per bunch, bunch weight and average fruit weight of plontain cultivar Maricongo producing between 30 and 40 fruits per bunch

\begin{tabular}{ccccccc}
\hline Soil pH & $\begin{array}{c}\text { Exchangeable } \\
\text { Al meq/100g }\end{array}$ & $\begin{array}{c}\text { Exchange- } \\
\text { able bases } \\
\text { meq } / 100 \mathrm{~g}\end{array}$ & $\begin{array}{c}\text { Base } \\
\text { saturation }\end{array}$ & $\begin{array}{c}\text { Number of } \\
\text { fruits }\end{array}$ & $\begin{array}{c}\text { Weight of } \\
\text { bunch }\end{array}$ & $\begin{array}{c}\text { Weight per } \\
\text { fruit }\end{array}$ \\
\hline & & & $\%$ & & $K g$ & $G$ \\
$4.4-4.6$ & 3.10 & 0.65 & 17 & 35 & 10.4 & 281 \\
$4.6-4.8$ & 2.05 & 2.05 & 50 & 36 & 11.1 & 300 \\
$>4.8$ & 0.37 & 4.47 & 92 & 31 & 9.1 & 295 \\
\hline
\end{tabular}


TABLE 5.-The effect of soil $\mathrm{pH}$ and related acidity factors on number of fruits per bunch, bunch weight and average fruit weight of plantain cultivar Maricongo producing between 20 and 30 fruits per bunch

\begin{tabular}{ccccccc}
\hline Soil pH & $\begin{array}{c}\text { Exchangea- } \\
\text { ble Al meq } \\
100 \mathrm{~g}\end{array}$ & $\begin{array}{c}\text { Exchangea- } \\
\text { ble bases } \\
\text { meq/100g }\end{array}$ & $\begin{array}{c}\text { Base satu- } \\
\text { ration }\end{array}$ & $\begin{array}{c}\text { Number of } \\
\text { fruits }\end{array}$ & $\begin{array}{c}\text { Weight of } \\
\text { bunch }\end{array}$ & $\begin{array}{c}\text { Weight per } \\
\text { fruit }\end{array}$ \\
\hline & & & $\%$ & & $K g$ & $G$ \\
$4.4-4.6$ & 2.42 & 1.58 & 40 & 22 & 7.6 & 354 \\
$4.6-4.8$ & 1.96 & 2.07 & 51 & 25 & 8.6 & 350 \\
$>4.8$ & 0.72 & 4.49 & 86 & 25 & 7.7 & 313 \\
\hline
\end{tabular}

TABLE 6.-The effect of soil $p H$ and related acidity factors on number of fruits per bunch, bunch weight and weight per fruit of plantains cultivar Maricongo grown on Los Guineos clay, an Ultisol, (first ratoon)

\begin{tabular}{ccccccc}
\hline Soil pH & $\begin{array}{c}\text { Exchangea- } \\
\text { ble Al meq/ } \\
100 \mathrm{~g}\end{array}$ & $\begin{array}{c}\text { Exchangea- } \\
\text { ble bases } \\
\text { meq/100 }\end{array}$ & $\begin{array}{c}\text { Base satu- } \\
\text { ration }\end{array}$ & $\begin{array}{c}\text { Number of } \\
\text { fruits per } \\
\text { bunch }\end{array}$ & $\begin{array}{c}\text { Bunch } \\
\text { weight }\end{array}$ & Fruit weight \\
\hline & & & $\%$ & & $K g$ & $g$ \\
$4.3-4.5$ & 5.09 & 2.90 & 36 & 29 & 8.4 & 291 \\
$4.6-4.8$ & 3.47 & 4.40 & 56 & 28 & 7.3 & 259 \\
$>4.8$ & 1.11 & 8.18 & 88 & 26 & 6.9 & 263 \\
\hline
\end{tabular}

TABLE 7.-The effect of soil pH on foliar composition of plantains cultivar Maricongo grown on Los Guineos clay, an Ultisol, (first ratoon)

\begin{tabular}{ccccccc}
\hline & \multicolumn{7}{c}{ Foliar Composition } \\
\cline { 2 - 7 } & $\mathrm{N}$ & $\mathrm{P}$ & $\mathrm{K}$ & $\mathrm{Ca}$ & $\mathrm{Mg}$ & $\mathrm{Mn}$ \\
\hline & $\%$ & $\%$ & $\%$ & $\%$ & $\%$ & $p / m$ \\
$4.3-4.5$ & 2.83 & 0.15 & 2.21 & 0.51 & 0.32 & 145 \\
$4.6-4.8$ & 2.78 & 0.16 & 2.18 & 0.46 & 0.31 & 105 \\
$>4.8$ & 3.13 & 0.16 & 1.93 & 0.63 & 0.31 & 108 \\
\hline
\end{tabular}

Right after harvest, four soil samples were taken around each plant, to a depth of $30 \mathrm{~cm}$. (40 experimental plants in all). Exchangeable Al, bases, $\mathrm{pH}$ and percentage base saturation were determined in each soil sample, and their values correlated with individual plant values relative to number of fruits per bunch, bunch weight and mean fruit weight.

The second plantain crop (first ratoon) was conditioned right after soil samples had been collected, and treated the same as the plant crop, regarding fertilizer, pesticide, leaf and soil sampling. The harvest lasted from May 17, 1977, to August 31, 1977.

\section{RESULTS AND DISCUSSIONS}

The effect of soil $\mathrm{pH}$ and related acidity factors on number of fruits per bunch, weight of bunch and mean fruit weight of plantains (cv Mari- 
congo), is shown in table 1 . The only significant correlation, $r=0.47^{*}$, was obtained between soil $\mathrm{pH}(0-30 \mathrm{~cm}$ depth) and number of fruits per bunch. The effect was quadratic, with $Y=322.73+134.41 \mathrm{X}-12.32 \mathrm{X}^{2}$ to predict number of fruits per bunch at a particular $\mathrm{pH}$ ranging from 4.4 and 5.2. Even though $\mathrm{pH}$ is in itself a function of the hydroylsis of some free and colloidal salts, including those of $\mathrm{Al}, \mathrm{Ca}$ and $\mathrm{Mg}$, no significant correlation was obtained when the exchangeable $\mathrm{Al}$ and bases were correlated with number of fruits, bunch weight and mean fruit weight.

Table 2 shows the effect of soil pH of the top $30 \mathrm{~cm}$ surface soil on foliar composition of plantains. Calcium was the only nutrient element which correlated in a highly significant way with number of fruits per bunch $(r=0.70)^{* *}$

Tables 3, 4 and 5 show data in an attempt to relate $\mathrm{pH}$ and acidity factors on plantains producing fruits within given ranges, namely, more than 40 plantains, between 30 and 40 plantains and between 20 and 30 . Statistical analyses showed no significant effect of $\mathrm{pH}$ and acidity factors on any of the indicated yield parameters.

The results of the second plantain crop (first ratoon) are shown on tables 6 and 7. Soil $\mathrm{pH}$ and acidity factors were not found to correlate with yield parameters. This behavior was reflected likewise on the foliar composition of the crop. The second crop yielded only $73 \%$ of the first. This was possibly due to the scarce rainfall $(1058 \mathrm{~mm})$ as compared to (2138 $\mathrm{mm})$, registered during the first crop and to damage caused by Cosmopolites sordidus.

Rather good yields were obtained on this soil with low $\mathrm{pH}$ values and correspondingly high amounts of exchangeable aluminum.

\section{RESUMEN}

En este trabajo se presentan los resultados de un estudio en el que se determinó el efecto del $\mathrm{pH}$ del suelo y los factores de acidez relacionados con él, en la producción de plátanos, cultivar Maricongo, sembrados en la arcilla Los Guineos, un Ultisol de la zona montañosa húmeda de Puerto Rico. El estudio reveló en la plantilla una correlación significativa, $r=$ 0.47 , entre el $\mathrm{pH}$ del suelo y el número de frutas por racimo, y otra altamente significativa, $r=0.70$, entre el contenido en calcio de las hojas, y el número de frutas. En el primer retoño no se registraron correlaciones significativas entre el $\mathrm{pH}$ del suelo y los factores de acidez relacionados y la producción de plátanos, ni entre el contenido en calcio de las hojas y la producción de los mismos. El cultivar Maricongo parece ser tolerante a niveles de pH bajos y a la correspondiente alta concentración de aluminio cambiable. 